herons. Eleven of the cormorant nests were in live and three were in dead balsam poplars. Another mixed colony of Double-crested Cormorants and Great Blue Herons in the Turtle Mountain area (no. 24), was in a flooded stand of dead aspen poplar. Both heron and cormorant nests varied greatly in height above the ground. Of the 20 active nests present, 11 were used by the cormorants and nine by the herons. A young Great Horned Owl (Bubo virginianus) was found in a former Great Blue Heron nest in the large heronry on Richard Point (no.
25). The tree in which the young owl was found contained two other nests with young herons. Common Grackles (Quiscalus quiscula) had built nests in the bottom of 12 heron nests in the same colony. Common Grackles were also observed nesting in the bottom of six Great Blue Heron nests in the heron colony at Kawinaw Lake in 1971.

\section{Acknowledgments}

The authors appreciate the help of at least 18 persons who provided information or asisisted with locating heronries.

\title{
TRAILL'S FLYCATCHER NESTING AT SASKATOON
}

\section{by Wayne C. Harris, Raymore}

At approximately 9:00 a.m. on July 23, 1971 a bird tentatively identified as a Traill's Flycatcher (Empidonax traillii) was observed by J. A. Wedgwood, S. J. Shaddick and myself four miles north and four miles west of Ardath (within the Saskatoon study area). The bird was giving alarm notes and seemed unwilling to leave the area. Though these actions led us to believe that there was a nest, a search of the area revealed nothing.

Another visit was made at 8:30 p.m. on the same day in an attempt to locate a nest. Following a thorough search, we flushed a small flycatcher from a small patch of rose bushes, and a nest containing four eggs was found $2 \frac{1}{2}$ feet high in the crotch of a rose bush. The habitat was shrubbery (rose, willow, red-osier dogwood, and snowberry) near the bank of a permanent creek. We left the area with the identification of the bird still in doubt as no singing male was heard in the vicinity of the nest.

On July 31, J. B. Gollop, J. A. Wedgwood and the writer revisited the nest in order to verify the identification of the bird. We found the female still on the nest and she was not flushed. Shortly, a male Traill's Flycatcher began singing from the top of a tree. A survey of the area revealed five Traill's Flycatcher in the vicinity (including the incubating female).
Another nest of the same construction as the first was found and, although the young had already fledged, it appeared that this nest was also that of a Traill's Flycatcher, something which could account for the number of birds of this species in the area.

When the female was finally flushed from the active nest, it was found to contain two eggs and two young. This was the last time the nest was visited; hence the outcome is not known.

Traill's Flycatcher was regarded as an uncommon migrant in the Saskatoon area and until this year there were no records between June 13 and August 19 (records from the "Saskatoon Bird Review"). This year there were several records between these dates. C. S. Houston observed one eight miles south of Saskatoon on June 19, and apparently the same individual was observed by the author in the same locality on June 22, 26, and July 5. A nest could not be located in this area although the bird was singing on three of the four sightings.

The above records not only constitute the first summer records but also include the only known breeding record for this area. This, however, is not the first breeding record for southern Saskatchewan; W. Earl Godfrey (The birds of Canada, Natl. Mus. Can. Bull. 203. 1966) states that Traill's Flycatcher breeds locally in the southern part of the province. 